\title{
KEPUASAN DAN LOYALITAS PETANI PADI TERHADAP PESTISIDA
}

\author{
Fibria Mustikarini ${ }^{1}$, Retnaningsih $^{\left.{ }^{*}\right)}$, Megawati Simanjuntak ${ }^{1}$ \\ ${ }^{1}$ Departemen IImu Keluarga dan Konsumen, Fakultas Ekologi Manusia, Institut Pertanian Bogor, \\ Bogor 16680, Indonesia \\ *) E-mail: lunafisa@yahoo.com
}

\begin{abstract}
Abstrak
Kepuasan dan loyalitas merupakan faktor penting untuk mempertahankan dan meningkatkan tingkat penjualan suatu produk. Tujuan dari penelitian ini adalah untuk menganalisis kepuasan dan loyalitas petani padi terhadap pestisida yang digunakan. Penelitian ini menggunakan disain cross sectional dengan jumlah contoh 100 petani yang diambil secara simple random sampling di Desa Cikarawang, Kecamatan Dramaga, Bogor, Jawa Barat. Pengumpulan data dilakukan dengan teknik wawancara menggunakan kuesioner. Penelitian ini menggunakan salah satu merek pestisida yang digunakan petani di lokasi penelitian. Hasil penelitian menunjukkan bahwa petani puas menggunakan pestisida tersebut dengan nilai customer satisfaction index sebesar 79,14 persen dan proporsi tingkat loyalitas petani terbanyak pada level habitual buyer sebesar 41 persen petani. Hasil analisis menunjukkan terdapat hubungan positif signifikan antara kelompok acuan petani dengan kepuasan petani terhadap pestisida merek tersebut. Selain itu, terdapat pula hubungan positif signifikan antara frekuensi penggunaan dengan loyalitas petani terhadap pestisida. Model menunjukkan bahwa pendapatan keluarga per kapita memengaruhi loyalitas petani terhadap pestisida merek acuan dalam penelitian ini.
\end{abstract}

Kata kunci: kepuasan, loyalitas, pestisida, petani padi

\section{Satisfaction and Loyalty to Pesticides among Paddy Farmers}

\begin{abstract}
Satisfaction and loyalty are important factors to mantain and to increase the level of sales. The purpose of this study was to analyze the satisfaction and loyalty to pesticides of paddy farmers. This study used crosssectional design with 100 farmers as samplesthat were chosen by simple random sampling in the village of Cikarawang, District Dramaga, Bogor, West Java. The data was collected by interview techniques using questionnaire. This research used one of pesticides brand that used by paddy farmers at study site. The results showed that the paddy farmers have already satisfied, this result was indicated by CSI value which was 79,14 percent and the proportion of loyalty level mostly in habitual buyer level as much as 41 percent farmers. The analysis revealed a significant positive correlation between the reference group of farmers and the satisfaction of farmers to the pesticides brand. In addition, there was also a significant positive correlation between the frequency of utilization and the brand loyalty of farmers. The model suggested that the family income per capita affect significantly on brand loyalty pesticides among paddy farmers.
\end{abstract}

Keywords: loyalty, paddy farmers, pesticides, satisfaction

\section{PENDAHULUAN}

Dinas Pertanian Tanaman Pangan Provinsi Jawa Barat tahun 2010 menyebutkan bahwa produksi padi di wilayah Bogor mengalami peningkatan pada tahun 2010 yaitu 529.866 ton dengan luas tanam padi sebesar 89.694 ha. Hal ini mengindikasikan bahwa semakin besar produktivitas padi sehingga permintaan terhadap teknologi pertanian seperti pupuk, pestisida, serta benih akan semakin meningkat. Pestisida digunakan untuk membasmi hama atau penyakit yang menyerang tanaman. Penggunaan pestisida memiliki tingkat risiko yang tinggi apabila digunakan bukan pada tempatnya. Berbagai macam merek pestisida beredar di pasaran.

Perusahaan yang memproduksi pestisida dengan beragam merek memiliki persaingan yang ketat. Dalam memerangi persaingan tersebut, perusahaan harus dapat menonjolkan kelebihan-kelebihan dari berbagai atribut yang ditawarkan. Apabila petani merasa tidak puas terhadap dampak penggunaan pestisida maka petani tersebut tidak akan melakukan pembelian dan penggunaan produk pestisida merek tersebut (Sumarwan, 2011). Oleh karena itu, produsen (perusahaan) harus mampu mempertahankan loyalitas dari penggunaan 
merek pestisida dengan memberikan kepuasan kepada konsumen khususnya petani. Loyalitas merek sangat terkait dengan kepuasan konsumen. Semakin puas seorang konsumen terhadap suatu merek maka konsumen akan semakin loyal terhadap merek tersebut (Sumarwan, 2011).

Setelah mengonsumsi produk atau jasa konsumen akan merasakan kepuasan atau ketidakpuasan terhadap produk atau jasa yang telah dikonsumsinya (Sumarwan, 2011). Hal ini merupakan penilaian evaluasi pascapembelian yang disebabkan oleh seleksi pembelian khusus dan pengalaman menggunakan atau mengonsumsi barang atau jasa tersebut. Kepuasan akan mendorong konsumen untuk melakukan pembelian ulang atas produk atau jasa yang telah dikonsumsi. Sebaliknya, perasaan tidak puas akan menghentikan konsumen untuk melakukan pembelian ulang. Kepuasan juga sebagai evaluasi pascakonsumsi bahwa suatu alternatif yang dipilih setidaknya bekerja sebaik yang diharapkan.

Pengukuran tingkat kepuasan suatu produk atau jasa dapat menggunakan Importance and Performance Analysis (IPA) dan Customer Satisfaction Index (CSI). IPA digunakan untuk mengetahui atribut apa saja yang perlu ditingkatkan maupun dipertahankan oleh perusahaan agar dapat melakukan perbaikan terhadap kinerjanya. Sementara itu, CSI digunakan untuk mengetahui kepuasan konsumen secara keseluruhan dari atribut yang diukur. Tingkat kepuasan yang tinggi dengan merek yang dimiliki sebelumnya sering disertai dengan sejumlah ketidakpuasan sesudah pembelian ulang. Hal ini terlihat dari kegagalan untuk melebihi harapan yang tinggi itu menyebabkan ketidakpuasan ringan. Penggunaan pestisida yang memenuhi harapan sehingga petani merasa manfaat pestisida dalam menekan jumlah hama dan penyakit dan pada akhirnya dapat meningkatkan produksi padi, tentu saja akan berpengaruh terhadap kepuasan petani terhadap produk pestisida yang digunakan.

Kepuasan petani terhadap pestisida yang digunakannya akan mengarahkan terhadap loyalitas petani. Loyalitas saat ini masih tetap menjadi pembicaraan yang sangat penting dan hangat dibicarakan dalam dunia pemasaran serta perilaku konsumen. Loyalitas merek (brand loyality) dapat diartikan sebagai sikap positif seorang konsumen terhadap suatu merek. Konsumen memiliki keinginan yang kuat untuk membeli ulang merek yang sama pada saat sekarang maupun untuk di masa yang akan datang. Keinginan kuat tersebut dibuktikan dengan selalu membeli merek yang sama. Loyalitas merek sangat terkait dengan kepuasan konsumen. Tingkat kepuasan konsumen akan memengaruhi derajat loyalitas merek seseorang. Namun, pada beberapa kasus loyalitas merek seringkali bukan disebabkan oleh kepuasan konsumen, tetapi karena keterpaksaan dan ketiadaan pilihan (Sumarwan, 2011).

Aaker (1997) menyebutkan beberapa tingkatan loyalitas merek yaitu: (1) pembeli yang berpindah-pindah (switcher buyer), (2) pembeli yang bersifat kebiasaan (habitual buyer), yaitu pembeli yang memilih suatu merek berdasarkan kebiasan, (3) pembeli yang puas dengan biaya peralihan (satisfied buyer), (4) menyukai merek (liking the brand), dan (5) pembeli yang setia (commited buyer). Pembeli yang berpindah-pindah merupakan tingkatan loyalitas yang paling rendah sementara pembeli yang setia menunjukkan tingkat loyalitas yang paling tinggi.

Kepuasan dan loyalitas konsumen dapat dipengaruhi beragam faktor, baik faktor internal konsumen maupun faktor eksternal.Pendidikan dan tingkat pendapatan seseorang akan memengaruhi proses keputusan dan pola konsumsi seseorang (Sumarwan, 2011). Menurut Huang et al. (2009), penyedia retailing delivery (RD) harus dapat fokus dalam informasi yang berkualitas (informasi tepat waktu dan akurat) dan prosedur pemesanan untuk meningkatkan kualitas pelayanan. Hal ini senada dengan hasil penelitian Sofyan, Prdhanawati, dan Nugraha (2013) yang menunjukkan bahwa fasilitas dan kualitas pelayanan menjadi faktor penting yang memengaruhi loyalitas konsumen. Beberapa faktor yang memengaruhi kepuasan konsumen yaitu faktor kebersihan, karakteristik produk, karakteristik penjual, warna produk, keramahan daya tanggap penjual, dan bauran pemasaran (Djamaludin, Sumarwan, dan Mahardikawati, 2009). Suwarni dan Mayasari (2011); Nurlaili dan Wijayanto (2013) juga menemukan bahwa kualitas produk dan harga memengaruhi kepuasan dan loyalitas konsumen. Selain itu, Musanto (2004) menyebutkan bahwa pengalaman penjual memberikan kontribusi terbesar terhadap loyalitas konsumen. Penjual yang berpengalaman dapat memengaruhi 
loyalitas konsumen untuk tetap menggunakan produk yang dijualnya.

Pada penggunaan pestisida, berbagai evaluasi akan dilakukan oleh petani sebagai konsumen setelah menggunakan pestisida. Hasil penelitian Isaskar, Wahib, dan Afriana (2010) yang dilakukan pada petani jagung menemukan bahwa dalam menentukan jenis insektisida yang akan digunakan, petani mempertimbangkan berbagai hal seperti merek, mutu, harga, sifat produk, dan kemasan. Berbagai atribut atau variabel akan memengaruhi evaluasi pascakonsumsi pestisida. Hal ini akan menghasilkan kepuasan atau ketidakpuasan dari petani dalam penggunaan pestisida. Selain itu, loyalitas petani dalam penggunaan pestisida juga memungkinkan dipengaruhi oleh berbagai atribut atau variabel tersebut. Petani akan merasa puas apabila hasil yang dirasakan sesuai dengan apa yang petani harapkan sebelum menggunakan pestisida (Sumarwan, 2011).

Berdasarkan rumusan yang telah disusun maka tujuan dari penelitian ini yaitu: (1) menganalisis perilaku penggunaan pestisida pada petani padi, (2) menganalisis tingkat kepuasan dan loyalitas petani padi pada pestisida, (3) mengetahui hubungan faktor individu, lingkungan, dan perilaku penggunaan dengan tingkat kepuasan dan loyalitas petani padi pada pestisida, dan (4) menganalisis faktor-faktor yang memengaruhi kepuasan dan loyalitas petani padi pada pestisida.

\section{METODE}

Penelitian ini menggunakan desain cross sectional dengan metode survei. Penelitian ini dilakukan di Desa Cikarawang, Kecamatan Dramaga, Kabupaten Bogor, Jawa Barat. Penentuan lokasi dipilih secara purposive dengan pertimbangan Desa Cikarawang merupakan desa yang memiliki total luas lahan terbesar di Kecamatan Dramaga. Metode pemilihan contoh yang digunakan adalah simple random sampling dengan jumlah contoh sebanyak 100 petani padi. Contoh dalam penelitian ini adalah petani yang tergabung dalam Gabungan Kelompok Tani (Gapoktan).

Penelitian ini menggunakan data primer yang meliputi faktor individu, faktor lingkungan, perilaku penggunaan, kepuasan, dan loyalitas. Faktor indivisu terdiri atas usia, pendidikan, pendapatan, dan luas lahan. Faktor lingkungan meliputi pengalaman mengikuti pelatihan, sumber informasi, dan kelompok acuan, sedangkan perilaku penggunaan yang diteliti terdiri atas frekuensi, jumlah, jadwal penyemprotan, dan penggunaan sesuai aturan pakai.

Data dikumpulkan dengan wawancara menggunakan kuesioner. Instrumen yang digunakan merupakan instrumen yang telah dimodifikasi peneliti dari penelitian sebelumnya oleh Suciatmasari (2012). Instrumen tersebut telah diuji reliabilitasnya dengan nilai Cronbach's alpha 0,738 (tingkat kepentingan pada variabel kepuasan), 0,849 (tingkat kinerja pada variabel kepuasan), dan sebesar 0,875 (variabel loyalitas).

Analisis yang digunakan dalam penelitian ini adalah analisis deskriptif dan inferensial yang meliputi uji korelasi (Spearman dan Pearson), Chi-Square, dan uji regresi logistik. Uji regresi logistik digunakan untuk menganalisis faktor-faktor yang memengaruhi kepuasan dan loyalitas petani. Selain itu, Importance and Performance Analysis (IPA) dan Customer Satisfaction Index (CSI) digunakan untuk menganalisis kepuasan dan analisis loyalitas berdasarkan Aaker (1997).

\section{HASIL}

\section{Faktor Individu dan Lingkungan Petani}

Hasil penelitian menunjukkan lebih dari separuh petani $(54,0 \%)$ berada pada kategori usia separuh baya dengan rentang 36 sampai dengan 50 tahun dan sebesar 75 persen petani berjenis kelamin laki-laki. Hampir separuh petani $(48,0 \%)$ memiliki pendidikan setingkat SD. Sebanyak 36 persen petani mempunyai pendapatan keluarga per bulan pada rentang Rp1.000.000,00 hingga Rp1.500.000,00. Sebanyak 84 persen petani memiliki luas lahan padi yang terkategori luas $(>0,25 \mathrm{ha}$ ) dan 85 persen petani menjadi pekerjaan utama. Lebih dari separuh petani sudah pernah mengikuti pelatihan $(55,0 \%), 78$ persen memiliki sumber informasi dari teman, dan 63 persen memilih keluarga sebagai kelompok acuan petani.

\section{Perilaku Penggunaan Pestisida}

Hasil penelitian menunjukkan lebih dari separuh petani $(58,0 \%)$ mengaku jarang (1-3 kali) menyemprotkan pestisida dan 79 persen petani sedikit menggunakan pestisida dengan kisaran satu sampai dengan dua botol pada satu kali musim tanam (1 botol $=50 \mathrm{ml}$ ). Hasil penelitian juga menunjukkan bahwa sebanyak 84 persen petani tidak tepat waktu dalam 
menyemprotkan pestisida dan 77 persen petani mengaku menggunakan pestisida tidak sesuai dengan aturan pakai. Lebih dari separuh petani $(53,0 \%)$ membeli pestisida di warung yang ada di sekitar tempat tinggal.

\section{Tingkat Kepuasan dengan Metode Importance Performance Analysis (IPA)}

Berdasarkan Gambar 1, diketahui rata-rata penilaian tingkat kepentingan dan tingkat kinerja untuk setiap atribut sebesar 4,33 dan 3,94 dan hal ini menggambarkan nilai antara apa yang dianggap penting (importance) oleh petani dengan kinerja (performance) yang diberikan oleh perusahaan. Nilai rata-rata ini digunakan untuk membagi garis batas antara tingkat kepentingan dan kinerja. Diagram Kartesius digunakan untuk melihat atribut apa saja yang harus diperbaiki atau ditingkatkan dari kinerja pestisida yang digunakan pada kuadran I, II, III, dan IV. Atribut harga dan kualitas termasuk dalam kuadran I yang berarti bahwa atribut tersebut termasuk dalam kategori prioritas utama untuk diperbaiki atau ditingkatkan. Pada kuadran II, terdapat atribut manfaat, sertifikasi, ketuntasan dalam mengendalikan hama, dan kecepatan daya bunuh termasuk dalam kategori untuk dipertahankan prestasinya. Hal ini memiliki arti bahwa atribut-atribut tersebut sudah dapat memuaskan petani sehingga perusahaan harus mempertahankan kinerjanya.

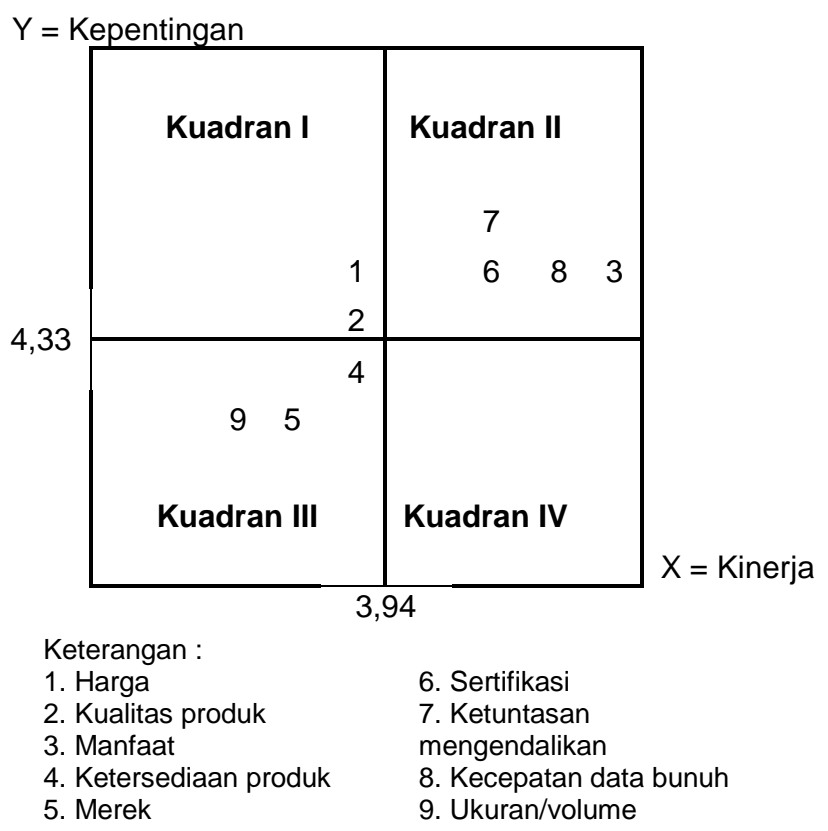

Atribut ketersediaan produk, merek, dan ukuran/volume termasuk dalam kuadran III yang terkategori prioritas rendah. Artinya, atribut dalam kuadran ini dianggap tidak penting oleh petani dan kenyataan kinerja dari perusahaan pun tidak terlalu baik sehingga perusahaan belum perlu melakukan perbaikan. Sementara itu, penelitian ini tidak menemukan adanya atribut baik pada tingkat kepentingan petani maupun tingkat kinerja produsen pestisida yang berada pada Kuadran IV.

\section{Tingkat Kepuasan dengan Metode Customer Satisfaction Index (CSI)}

Indeks Kepuasan Konsumen (CSI) diukur berdasarkan rata-rata tingkat kepentingan dan kinerja masing-masing atribut pestisida. Angka CSI yang diperoleh dalam penelitian ini sebesar 79,14 persen. Nilai CSI tersebut berada pada rentang 61 hingga 80 persen dengan kriteria puas. Hal ini berarti secara umum petani telah merasa puas dengan kinerja yang diberikan oleh produsen pestisida yang petani gunakan. Nilai 79,14 persen berarti produsen pestisida yang digunakan petani telah memenuhi harapan petani terhadap produk berdasarkan atribut-atributnya sebesar 79,14 persen. Sisanya sebesar 20,86 persen harapan petani belum mampu dipuaskan oleh produsen pestisida. Perhitungan Costumer Satisfaction Index (CSI) pestisida disajikan pada Tabel 1.

Tabel 1 Perhitungan Costumer Satisfaction Index (CSI) pestisida

\begin{tabular}{|c|c|c|c|c|}
\hline Atribut & $\mathrm{RSP}$ & WF & RSK & WS \\
\hline Harga & 4,57 & 0,117 & 3,8 & 0,444 \\
\hline Kualitas & 4,51 & 0,115 & 3,91 & 0,451 \\
\hline Manfaat & 4,5 & 0,115 & 4,14 & 0,477 \\
\hline Ketersediaan & 4,3 & 0,110 & 3,84 & 0,422 \\
\hline Merek & 3,75 & 0,096 & 3,8 & 0,364 \\
\hline Sertifikasi & 4,35 & 0,111 & 3,94 & 0,438 \\
\hline $\begin{array}{l}\text { Ketuntasan } \\
\text { dalam } \\
\text { mengendalika } \\
\mathrm{n} \text { hama }\end{array}$ & 4,59 & 0,117 & 4,27 & 0,501 \\
\hline $\begin{array}{l}\text { Kecepatan } \\
\text { daya bunuh }\end{array}$ & 4,58 & 0,117 & 4,38 & 0,513 \\
\hline Ukuran/volume & 3,9 & 0,099 & 3,42 & 0,341 \\
\hline Total & 39,05 & 1 & 35,5 & \\
\hline \multicolumn{4}{|c|}{ Weighted Average } & 3,957 \\
\hline \multicolumn{4}{|c|}{ Costumer Satisfaction Index (\%) } & 79,14 \\
\hline \multicolumn{5}{|c|}{$\begin{array}{l}\text { Keterangan: } \\
\text { RSP = Rata-rata skor kepentingan (RSP) } \\
\text { WF = Weighting Factor [WF = RSP/total RSP] } \\
\text { RSK = Rata-rata skor kinerja (RSK) } \\
\text { WS = Weighting Score }[\text { WS = RSK } \times \text { WF] }\end{array}$} \\
\hline
\end{tabular}

\section{Gambar 1 Diagram kartesius penggunan pestisida}




\section{Loyalitas}

Tingkatan loyalitas terdiri dari pembeli yang berpindah-pindah (switcher buyer), pembeli yang bersifat kebiasaan (habitual buyer), pembeli yang puas (satisfied buyer), pembeli yang menyukai merek (liking the brand), dan pembeli yang setia (commited buyer). Analisis loyalitas dalam penelitian ini menggunakan metode analisis loyalitas menurut Aaker (1997). Tabel 2 menunjukkan jumlah dan persentase tingkat loyalitas petani pengguna pestisida merek acuan yang dipilih dalam penelitian ini.

Hampir separuh $(41,0 \%)$ petani termasuk dalam tingkatan loyalitas habitual buyer, yaitu petani yang puas terhadap merek yang dikonsumsinya atau setidaknya tidak merasa ketidakpuasan dalam mengkonsumsi merek tersebut dan membeli pestisida merek acuan atas dasar kebiasaan selama ini. Sebanyak 22 persen petani termasuk dalam liking the brand, yaitu konsumen yang sungguh-sungguh menyukai merek tersebut yang didasari oleh rangkaian pengalaman dalam menggunakan merek pestisida sebelumnya, 15 persen petani termasuk dalam satisfied buyer, yaitu konsumen yang merasa puas terhadap merek pestisida yang digunakan, dan 11 persen petani masing-masing termasuk dalam tingkatan loyalitas switcher buyer (termasuk konsumen yang tidak setia) dan commited buyer (pembeli yang setia bahkan merekomendasikan merek tersebut kepada orang lain).

\section{Hubungan Faktor Individu, Lingkungan, dan Perilaku Penggunaan dengan Kepuasan dan Loyalitas Petani terhadap Pestisida}

Berdasarkan hasil uji korelasi Spearman pada Tabel 3, terdapat hubungan yang positif signifikan antara kelompok acuan petani dengan kepuasan $(r=0,230, \quad p<0,05)$ dan loyalitas petani $(r=0,179, \quad p<0,1)$ terhadap pestisida yang digunakan. Hal ini berarti keluarga sebagai kelompok acuan petani memiliki peranan yang positif dalam memengaruhi petani untuk merasa puas dan loyal terhadap pestisida yang digunakan.

Tabel 2 Sebaran tingkatan loyalitas petani terhadap pestisida yang digunakan

\begin{tabular}{lr}
\hline \multicolumn{1}{c}{ Tingkatan loyalitas } & Persentase \\
\hline Switcher buyer & 11,0 \\
Habitual buyer & 41,0 \\
Satisfied buyer & 15,0 \\
Liking the brand & 22,0 \\
Commited buyer & 11,0 \\
\hline Total & 100,0 \\
\hline
\end{tabular}

Tabel 3 Hubungan faktor individu, lingkungan, dan perilaku penggunaan dengan kepuasan dan loyalitas petani dalam penggunaan pestisida

\begin{tabular}{|c|c|c|}
\hline Variabel & Kepuasan & Loyalitas \\
\hline Usia (tahun) & $-0,048$ & $-0,110$ \\
\hline Pendidikan (tahun) & 0,046 & 0,100 \\
\hline $\begin{array}{l}\text { Pendapatan keluarga } \\
\text { perkapita (rupiah) }\end{array}$ & 0,024 & 0,163 \\
\hline Luas lahan (ha) & 0,013 & 0,071 \\
\hline $\begin{array}{l}\text { Pengalaman mengikuti } \\
\text { pelatihan }(0=\text { belum pernah; } \\
1=\text { sudah pernah) }\end{array}$ & 0,053 & $-0,042$ \\
\hline $\begin{array}{l}\text { Sumber informasi } \\
\text { (0=lainnya; } 1=\text { teman) }\end{array}$ & 0,004 & $-0,014$ \\
\hline $\begin{array}{l}\text { Kelompok acuan ( } 0=\text { lainnya; } \\
1=\text { keluarga) }\end{array}$ & $0,230^{*}$ & 0,753 \\
\hline si penggunaan (kali) & 0,154 & $0,211^{*}$ \\
\hline stisida (m & 0,070 & $0,189^{*}$ \\
\hline Jadwal penyemprotan & $-0,051$ & $-0,087$ \\
\hline $\begin{array}{l}\text { Penggunaan sesuai dengan } \\
\text { aturan pakai }\end{array}$ & $-0,007$ & $-0,1$ \\
\hline
\end{tabular}

Keterangan:

*Signifikan pada $p<0,05$ dan $p<0,1$

Tabel 3 menyajikan antara hubungan faktor individu, lingkungan, dan perilaku penggunaan dengan kepuasan dan loyalitas petani dalam penggunaan pestisida. Hasil uji korelasi menemukan bahwa frekuensi penggunaan pestisida memiliki hubungan positif signifikan dengan loyalitas petani terhadap pestisida yang digunakan $(r=0,211$, $p<0,05)$. Hal ini berarti semakin sering petani menggunakan pestisida dengan merek tertentu maka petani akan semakin loyal dan menjadi pembeli yang setia untuk membeli pestisida merek tersebut, serta dapat mempromosikan atau menyarankan kepada orang lain untuk menggunakan pestisida tersebut.

\section{Hubungan Kepuasan dengan Loyalitas Petani terhadap Pestisida}

Hasil uji korelasi juga menunjukkan bahwa terdapat hubungan positif signifikan antara kepuasan dan loyalitas petani terhadap merek pestisida yang digunakan $(r=0,180, p<0,1)$. Hal ini berarti semakin tinggi rasa puas petani maka semakin loyal petani terhadap penggunaan pestisida merek tersebut.

\section{Faktor-faktor yang Memengaruhi Kepuasan Petani terhadap Pestisida}

Faktor-faktor yang memengaruhi kepuasan petani terhadap pestisida dianalisis menggunakan analisis regresi logistik yang diukur berdasarkan jawaban petani mengenai kepuasan menggunakan pestisida. Petani yang termasuk dalam kategori puas adalah petani yang memiliki total skor lebih dari sama dengan rata-rata total skor kepuasan, sedangkan petani 
yang termasuk dalam kategori tidak puas memiliki total skor yang kurang dari rata-rata total skor kepuasan. Variabel bebas yang dimasukkan ke dalam model dan diduga memengaruhi kepuasan petani menggunakan pestisida meliputi usia, pendidikan, pendapatan keluarga per kapita, luas lahan, pengalaman mengikuti pelatihan, kelompok acuan, sumber informasi, frekuensi penggunan, jumlah penggunaan, jadwal penyemprotan pestisida, dan penggunaan sesuai dengan aturan pakai.

Berdasarkan hasil analisis regresi logistik pada Tabel 4, variabel bebas memberikan pengaruh yang signifikan terhadap model atau dengan kata lain model ini dinyatakan fit (Chisquare=12,904, $d f=6, p<0,05)$. Selain itu, signifikansi Chi-square pada Tabel Hosmer dan Lemeshow test lebih dari 0,05 ( $>>0,05)$. Hal ini berarti model ini dapat diterima dan digunakan dalam pengujian hipotesis dengan keberhasilan prediksi secara umum sebesar 72 persen. Nilai Nagelkerke $R$ Square yang diperoleh dari analisis tersebut adalah sebesar 0,163. Artinya, model hanya menjelaskan sebesar 16,3 persen faktor-faktor yang berpengaruh terhadap kepuasan merek pestisida yang digunakan petani, selebihnya yaitu 83,7 persen pengaruh dijelaskan oleh variabel lain yang tidak terdapat dalam model penelitian.

Tabel 4 Faktor-faktor yang memengaruhi kepuasan petani terhadap pestisida

\begin{tabular}{|c|c|c|c|}
\hline \multirow{2}{*}{$\begin{array}{l}\text { Variabel } \\
\text { independen }\end{array}$} & \multicolumn{3}{|c|}{$\begin{array}{c}\text { Kepuasan menggunakan pestisida } \\
(0=\text { tidak puas, } 1=\text { puas })\end{array}$} \\
\hline & $\mathrm{B}$ & $\operatorname{Exp}(B)$ & Sig. \\
\hline Konstanta & $-0,554$ & 0,575 & 0,652 \\
\hline Usia (tahun) & $-0,018$ & 0,982 & 0,394 \\
\hline $\begin{array}{l}\text { Luas lahan } \\
\text { (ha) }\end{array}$ & $-0,914$ & 0,401 & 0,178 \\
\hline $\begin{array}{l}\text { Pengalaman } \\
\text { mengikuti } \\
\text { pelatihan } \\
\text { (1=sudah } \\
\text { pernah; } \\
0=\text { belum } \\
\text { pernah) }\end{array}$ & $-0,293$ & 0,746 & 0,518 \\
\hline $\begin{array}{l}\text { Sumber } \\
\text { informasi } \\
\text { (1=teman; } \\
0=\text { lainnya) }\end{array}$ & 0,734 & 2,084 & 0,164 \\
\hline $\begin{array}{l}\text { Kelompok } \\
\text { acuan } \\
\text { (1=keluarga; } \\
0=\text { lainnya) }\end{array}$ & 0,339 & 1,404 & 0,326 \\
\hline $\begin{array}{l}\text { Frekuensi } \\
\text { penggunaan } \\
\text { (kl/musim) }\end{array}$ & 0,406 & 1,500 & $0,007^{\star}$ \\
\hline NagelkerkeR $^{2}$ & 0,163 & & \\
\hline
\end{tabular}

Faktor-faktor yang Memengaruhi Loyalitas Petani terhadap Pestisida

Faktor-faktor yang memengaruhi loyalitas untuk menggunakan pestisida dianalisis dengan menggunakan analisis regresi logistik yang diukur berdasarkan sebaran jawaban petani mengenai loyalitas dalam pembelian dan penggunaan pestisida. Petani yang termasuk dalam kategori loyal adalah petani yang memiliki total skor lebih dari sama dengan ratarata total skor loyalitas secara keseluruhan, sedangkan petani yang termasuk dalam kategori tidak loyal memiliki total skor yang kurang dari rata-rata total skor loyalitas.

Selanjutnya pada Tabel 5 , hasil analisis regresi logistik menunjukkan bahwa variabel bebas berpengaruh nyata terhadap model (Chisquare $=15,277, d f=7, \quad p<0,05)$. Selain itu, signifikansi Chi-square pada Tabel Hosmer dan Lemeshow test lebih dari 0,05 ( $p>0,05)$. Artinya, model ini dapat diterima dan digunakan dalam pengujian hipotesis dengan keberhasilan prediksi secara umum sebesar 64 persen. Nilai Nagelkerke $R$ Square sebesar 0,189 , artinya model hanya menjelaskan sebesar 18,9 persen faktor-faktor yang berpengaruh terhadap loyalitas petani terhadap merek pestisida yang digunakan. Sisanya, sebesar 81,1 persen dijelaskan oleh variabel lain yang tidak diteliti.

Tabel 5 Faktor-faktor yang memengaruhi loyalitas petani terhadap pestisida

\begin{tabular}{|c|c|c|c|}
\hline \multirow[t]{2}{*}{$\begin{array}{l}\text { Variabel } \\
\text { independen }\end{array}$} & \multicolumn{3}{|c|}{$\begin{array}{c}\text { Loyalitas penggunaan } \\
\text { pestisida }(0=\text { tidak loyal, } \\
1=\text { loyal })\end{array}$} \\
\hline & $B$ & $\operatorname{Exp}(B)$ & Sig. \\
\hline Konstanta & $-2,916$ & 0,054 & 0,231 \\
\hline Usia (tahun) & $-0,024$ & 0,976 & 0,327 \\
\hline $\begin{array}{l}\text { Pendidikan } \\
\text { (tahun) }\end{array}$ & $-0,061$ & 0,941 & 0,378 \\
\hline $\begin{array}{l}\text { Pendapatan } \\
\text { keluarga per } \\
\text { kapita (Rp) }\end{array}$ & 0,003 & 1,003 & $0,018^{*}$ \\
\hline $\begin{array}{l}\text { Pengalaman } \\
\text { mengikuti } \\
\text { pelatihan } \\
\text { ( } 1=\text { sudah pernah; } \\
0=\text { belum pernah) }\end{array}$ & $-0,320$ & 0,726 & 0,481 \\
\hline $\begin{array}{l}\text { Kelompok acuan } \\
\text { (1=keluarga; } \\
0=\text { lainnya) }\end{array}$ & 0,489 & 1,631 & 0,114 \\
\hline $\begin{array}{l}\text { Frekuensi } \\
\text { penggunaan } \\
\text { (kl/musim) }\end{array}$ & 0,127 & 1,136 & 0,254 \\
\hline Kepuasan & 0,076 & 1,079 & 0,178 \\
\hline Nagelkerke $\mathrm{R}^{2}$ & & 0,189 & \\
\hline
\end{tabular}

Keterangan:

${ }^{*}$ Signifikan pada $p<0,05$ 


\section{PEMBAHASAN}

Pestisida merupakan kebutuhan dasar bagi petani yang berguna untuk membasmi hama dan penyakit yang menyerang tanaman di lahan sawah yang petani tanami. Penelitian ini menemukan bahwa frekuensi penggunaan pestisida oleh petani dapat dikatakan baik. Menurut Supriatna dan Sadikin (1998), frekuensi penggunaan pestisida dilakukan satu sampai dengan dua minggu sekali tergantung dari intensitas serangan hama atau penyakit. Apabila tidak terdapat hama maka frekuensi penyemprotan dilakukan kurang lebih tiga kali dalam satu kali musim tanam dan delapan kali penyemprotan apabila terdapat hama atau penyakit. Sahara dan Idris (2005) menyatakan bahwa jumlah penggunaan pestisida bergantung dari luas lahan yang dimiliki oleh petani dan penentuan jumlah pestisida yang digunakan tercantum dalam label kemasan dan disesuaikan dengan hama dan penyakit yang menyerang.

Jadwal penyemprotan yang dilakukan petani sudah baik yaitu dilakukan secara tidak teratur. Supriatna dan Sadikin (1998) menyatakan bahwa jadwal penyemprotan yang baik adalah yang tepat waktu. Artinya, penyemprotan baru boleh dilaksanakan apabila terlebih dahulu petani sudah melakukan pengamatan dan diketahui bahwa intensitas gangguan hama dan penyakit sudah di atas ambang ekonomis. Ambang ekonomi merupakan tingkat populasi hama dimana tindakan pengendalian dianjurkan untuk mencegah jumlah hama mencapai tingkat kerugian ekonomi. Lebih dari separuh petani $(77,0 \%)$ menggunakan pestisida tidak sesuai aturan pakai. Hal ini dapat dikatakan tidak baik. Seharusnya, penggunaan dosis pestisida sesuai anjuran atau yang tertera pada label kemasan produk pestisida. Namun, nyatanya petani di lokasi penelitian cenderung tidak menggunakan dosis pestisida sesuai anjuran pada label.

Pengukuran kepuasan masing-masing atribut menyebabkan pihak-pihak yang melakukan kegiatan pengembangan dan peningkatan mutu suatu produk dapat lebih terarah dalam melihat atribut produk yang memiliki tingkat kepentingan tinggi bagi konsumen, tetapi memiliki kepuasan yang rendah. Pemetaan berdasarkan tingkat kepentingan dan tingkat kinerja (IPA), memungkinkan pihak produsen pestisida mengetahui atribut apa saja yang sudah baik, berlebihan, dan perlu diperbaiki kinerjanya. $\mathrm{Hal}$ ini sangat bergantung dari posisi atribut pada diagram kartesius yang terbagi menjadi empat kuadran sehingga diharapkan perbaikan yang dilakukan dapat memenuhi kepuasan petani terhadap pestisida yang digunakan.

Kuadran I disebut sebagai atribut yang termasuk prioritas utama yaitu menunjukkan atribut yang dianggap dapat memengaruhi kepuasan konsumen karena termasuk unsurunsur yang dianggap sangat penting, namun perusahaan belum melaksanakannya sesuai dengan keinginan dari konsumen sehingga dirasa tidak puas. Atribut yang termasuk dalam kuadran ini harus menjadi prioritas utama bagi perusahaan untuk meningkatkan kepuasan konsumen. Kuadran II merupakan wilayah yang memuat faktor-faktor yang dianggap penting bagi konsumen dan sudah sesuai dengan yang dirasakannya sehingga tingkat kepuasannya relatif lebih tinggi. Atribut yang termasuk dalam Kuadran II harus tetap dipertahankan karena semua atribut ini menjadikan pestisida yang digunakan memiliki keunggulan dimata petani di lokasi penelitian. Kuadran III merupakan wilayah yang dianggap kurang penting bagi responden dan pada kenyataannya pun kinerja yang diperlihatkannya tidak terlalu istimewa. Perusahaan dalam hal ini belum perlu melakukan peningkatan terhadap atribut yang termasuk dalam Kuadran III ini.

Analisis loyalitas menunjukkan bahwa proporsi terbanyak petani yang loyal dengan merek pestisida yang digunakan berada pada level habitual buyer. Hal ini dikarenakan petani menggunakan merek pestisida tersebut karena sudah terbiasa dan menjadi tradisi turuntemurun sehingga petani cenderung sudah mengetahui kinerja yang diberikan pestisida tersebut dan petani merasa puas. Selain itu, sudah menjadi kebiasaan yang dilakukan petani untuk menggunakan pestisida merek tersebut, menjadi salah satu faktor yang menentukan banyaknya petani yang tergolong habitual buyer. Loyalitas petani terhadap merek insektisida tertentu terkait dengan keunggulan dari merek produk insektisida dibandingkan merek lain sehingga petani memutuskan untuk membeli insektisida dengan merek yang sama dengan pembelian sebelumnya (Purwanto, Hadiwidjojo, \& Ratnawati, 2013). Hasil penelitian ini didukung penelitian sebelumnya bahwa dalam menentukan merek pestisida yang akan digunakan, petani mempertimbangkan banyak hal (Isaskar, Wahib, \& Afriana, 2010). Pertimbangan tersebut bertujuan untuk mengetahui mutu dari jenis pestisida yang yang akan digunakan petani. 
Hasil penelitian ini menemukan bahwa kelompok acuan memiliki hubungan positif dengan kepuasan. Hasil menunjukkan bahwa lebih dari separuh petani memilih keluarga sebagai kelompok acuannya dalam mengambil keputusan dalam pembelian pestisida. Keluarga merupakan lingkungan yang paling dekat (mikro) dengan konsumen (Sumarwan, 2011). Hal ini berarti bahwa pada penelitian ini keluarga adalah lingkungn terdekat petani. Anggota keluarga saling memengaruhi satu sama lain dalam keputusan pembelian dan konsumsi suatu produk. Petani memiliki kepuasan dalam menggunakan merek pestisida yang telah digunakan karena sudah mengetahuinya dari pendahulunya seperti orang tua. Banyak petani yang memiliki anak atau orang tua yang rumah tempat tinggalnya dalam satu lingkungan. Rorlen (2007) menyatakan bahwa kelompok acuan dapat memengaruhi perilaku individu dengan memberitahukan dan mengusahakan agar individu menyadari adanya suatu produk atau merek khusus dan membenarkan keputusan untuk memakai produk-produk yang sama dengan kelompok.

Hasil penelitian juga menemukan bahwa frekuensi penggunaan pestisida memiliki hubungan positif dengan loyalitas petani dalam menggunakan merek pestisida yang selama ini digunakan. Hal ini terjadi karena frekuensi penggunaan pestisida yang terkategori sering akan menimbulkan perilaku pembelian pestisida yang cukup banyak. Menurut Herawaty dan Nadhira (2009), frekuensi penggunaan pestisida yang semakin sering menyebabkan petani menjadi optimis dengan hasil panen yang akan didapatkannya. Selain itu, merek yang sudah terkenal juga memengaruhi petani dalam melakukan transaksi pembelian pestisida karena merek yang sudah melekat di dalam pikiran petani.

Penelitian ini juga menemukan adanya hubungan yang positif antara kepuasan dan loyalitas petani terhadap merek pestisida yang selama ini digunakan. Hasil penelitian ini sesuai dengan pernyataan Sumarwan (2011) yang menyebutkan bahwa tingkat kepuasan konsumen akan memengaruhi derajat loyalitas merek seseorang. Hal tersebut menunjukkan bahwa semakin puas seorang konsumen terhadap suatu merek maka akan semakin loyal terhadap merek tersebut. Loyalitas merek akan menyebabkan munculnya komitmen merek, yaitu kedekatan emosional dan psikologis dari seorang konsumen terhadap suatu produk.
Hasil penelitian ini juga menemukan bahwa pendapatan keluarga per kapita memiliki peluang untuk meningkatkan loyalitas terhadap merek pestisida yang digunakan petani. Petani yang memiliki pendapatan keluarga per kapita yang tinggi tentunya akan berpikir cara untuk mengatasi adanya hama atau penyakit yang menyerang tanaman padi yang ditanam. Hal ini dapat dilakukan dengan pembelian dan penggunaan pestisida. Merek pestisida yang digunakan petani dalam penelitian ini telah cukup lama digunakan petani. Hal ini dikarenakan faktor kebiasaan dan petani sudah mengetahui kinerja pestisida tersebut dalam menumpas hama serta penyakit. Hal ini juga yang membuat petani menjadi loyal dengan merek pestisida tersebut. Menurut Sumarwan (2011), konsumen yang memiliki pendapatan keluarga per kapita yang tinggi akan membelanjakan barang berdasarkan kualitas barang tersebut walaupun dengan harga yang mahal dan jumlah pendapatan keluarga per bulan akan menggambarkan daya beli seorang konsumen.

\section{SIMPULAN DAN SARAN}

Penelitian menunjukkan bahwa frekuensi penggunaan dan jadwal penyemprotan pestisida oleh petani dapat dikatakan baik karena sudah sesuai dengan perilaku penggunaan pestisida secara umum. Jumlah pestisida yang digunakan juga sudah sesuai dengan jumlah takaran yang harus digunakan. Namun, penggunaan pestisida oleh petani masih tidak sesuai dengan dosis aturan pakainya. Hasil penelitian juga menemukan tingkat kepuasan petani terhadap merek pestisida yang digunakan termasuk dalam kategori puas (CSI=79,14\%). Atribut yang perlu ditingkatkan kinerjanya oleh perusahaan adalah atribut harga dan kualitas. Sementara itu, loyalitas petani paling banyak berada di level habitual buyer sebanyak 41 persen.

Hasil analisis lebih lanjut menemukan adanya hubungan positif antara kelompok acuan petani (keluarga) dengan kepuasan petani terhadap merek pestisida yang digunakan. Hal ini berarti keluarga memiliki peranan yang positif dalam memengaruhi kepuasan petani dalam menggunakan pestisida. Selain itu, terdapat pula hubungan positif antara frekuensi dan jumlah penggunaan dengan loyalitas petani terhadap merek pestisida yang digunakan. Selanjutnya, kepuasan memiliki hubungan yang positif signifikan dengan loyalitas petani dalam penggunaan pestisida. Hasil tersebut menunjukkan bahwa semakin puas petani 
dalam menggunakan pestisida, maka semakin loyal petani terhadap merek pestisida yang digunakan. Pendapatan keluarga per kapita petani juga memiliki peluang untuk meningkatkan loyalitas terhadap merek pestisida yang digunakan.

Hasil penelitian menunjukkan bahwa petani kurang memiliki pengetahuan tentang cara penggunaan pestisida yang sesuai dengan ketentuan yang tertera di label kemasan, dalam hal ini adalah pemberian dosis yang sesuai. Selain itu, kelompok yang menjadi acuan petani adalah keluarga, yang mana seharusnya pihak penyuluh pertanian yang menjadi acuan petani karena pihak penyuluh memiliki pengetahuan yang lebih dan benar mengenai pertanian. Saran yang diberikan oleh peneliti adalah pihak penyuluh pertanian secara rutin memberikan penyuluhan atau pelatihan bagi petani. $\mathrm{Pe}$ latihan atau penyuluhan dilakukan dengan tatap muka masing-masing petani atau dengan petani membentuk kelompok kecil agar pihak penyuluh menjadi efektif dalam memberikan penyuluhan dibandingkan dengan metode ceramah, yang mana pada saat penyuluhan seringkali petani tidak memperhatikan pihak penyuluh.

Pestisida yang digunakan oleh petani adalah pestisida kimia. Saat ini pemerintah sudah mencanangkan program agar petani menggunakan pestisida nabati (alami). Namun dalam perkembangannya, tidak semua petani menggunakan pestisida alami untuk tanamannya. Penggunaan pestisida alami sudah disosialisasikan oleh pemerintah. Hanya saja dalam praktiknya, petani masih belum berani untuk menggunakan pestisida alami karena kepercayaan dan pengalamannya dalam menggunakan pestisida kimia. Hal ini harus diantisipasi oleh pemerintah dengan rutin mengadakan pelatihan atau penyuluhan bahkan sampai dengan praktik pengajaran mengenai pembuatan pestisida alami. Selain itu, untuk menyukseskan program pemerintah agar petani menggunakan pestisida alami, pemerintah atau pihak penyuluh harus dapat mengubahpola pemikiran petani bahwa menggunakan pestisida alami jauh lebih menguntungkan jika dibandingkan dengan menggunakan pestisida kimia. Apabila petani sudah menggunakan pestisida alami, dalam penelitian selanjutnya dapat dilakukan dengan membandingkan petani yang menggunakan pestisida kimia dan pestisida alami untuk melihat kepuasannya dalam menggunakan pestisida.

\section{DAFTAR PUSTAKA}

Aaker, A. D. (1997). Manajemen ekuitas merek.Jakarta, ID: Mitra Utama.

Djamaludin, M. D., Sumarwan, U., \& Mahardikawati, G. N. A. (2009). Analisis kepuasan dan loyalitas konsumen jamu gendong di Kota Sukabumi.Jur. IIm. Kel. \& Kons., 2(2), 175-185.

Herawaty.\& Nadhira, A. (2009). Kajian penggunaan pestisida oleh petani pemakai serta informasi dari berbagai stakeholder terkait di Kabupaten Karo Sumatra Utara. Sekolah Tinggi Penyuluhan Pertanian Medan.

Huang Y. K., Kuo T. W., \& Xu S. W. (2009). Applying importance-performance analysis to evaluate logistics service quality for online shopping among retailing delivery. International Journal of Electronic Business Management, 7(2), 128-136.

Isaskar, R., Wahib, A., \& Afriana, R. (2010). Analisis preferensi petani jagung terhadap insektisida seed treatment. AGRISE, 10(3), 226-237. ISSN:1412-1425.

Nurlaili, \& Wijayanto, A. (2013). Analisis faktor yang memengaruhi loyalitas konsumen Tupperware. Jurnal Administrasi Bisnis, 2(1),89-97.

Musanto, T. (2004).Faktor-faktor kepuasan pelanggan dan loyalitas pelanggan: Studi kasus pada CV. Sarana Jurnal Manajemen dan Kewirausahaan, 6(2), 123-136. Diambil dari http://puslit. petra.ac.id. [diunduh 30 Jun 2012].

Rorlen. (2007). Peran kelompok acuan dan keluarga terhadap proses keputusan pembelian. Business \& Managemen Journal Bunda Mulia. Diambil darihttp:// www.ubm.ac.id/manajemen/imagesdoc/jo urnal/jurnal-peran-kelompok-acuan-rorlen. pdf. [diunduh 30 Jun 2012].

Sahara. D., \& Idris. (2005). Efisiensi produksi sistem usahatani padi pada lahan sawah irigasi teknis. Balai Pengkajian Teknologi Pertanian (BPTP) Sulawesi Tenggara. Diambil dari http://ejournal.unud.ac.id/ [diunduh 30 Jun 2012].

Sofyan, I. L., Prdhanawati, A., \& Nugraha, H. S. (2013). Pengaruh fasilitas dan kualitas pelayanan terhadap loyalitas, melalui kepuasan konsumen sebagai variabel intervening pada star clean car wash Semarang. Diponegoro Journal of Social and Politic, 1-12. Diambil dari 
http://ejournals1.undip.ac.id/index.php/.[di unduh 28 Jun 2012].

Suciatmasari, R. (2012). Analisis kepuasan dan loyalitas konsumen minyak goreng kemasan merek bimoli (skripsi). Institut Pertanian Bogor, Bogor.

Sumarwan, U. (2011). Perilaku konsumen teori dan penerapannya dalam pemasaran. Bogor, ID: Ghalia Indonesia.

Supriatna, A., \& Sadikin, I. (1998). Kinerja pengendalian hama padi sawah pasca introduksi teknologi pengendalian hama terpadu. Pusat Penelitian dan Pengembangan Sosial Ekonomi Pertanian
Bogor. Diambil dari http://ejournal. unud.ac.id/.[diunduh 30 Jun 2012].

Suwarni, \& Mayasari, S. D. (2011). Pengaruh kualitas produk dan harga terhadap loyalitas. Jurnal Ekonomi dan Bisnis, 16(1), 76-84. Diambil dari http://fe.um.ac.id. [diunduh28 Jun 2012].

Purwanto, E., Hadiwidjojo, D., \& Ratnawati, K. (2013). Preferensi merek sebagai pemediasi kesadaran merek dan asosiasi merek terhadap loyalitas konsumen (studi kasus produk insektisida Asmec 36EC di Malang Raya). Jurnal Aplikasi Manajemen, 11(2), 186-196. 